\title{
Electricity Crisis of Bangladesh: Result of Organizational Inefficiency?
}

\author{
Ziauddin Ahmed (Corresponding author) \\ Department of Public Policy and Management, the University of Melbourne \\ Parkville VIC 3010, Australia
}

Tel: 614-3080-9871_E-mail: ahmedz@student.unimelb.edu.au; zia_joy@yahoo.com

Received: August 29, 2011 Accepted: September 16, 2011 Published: December 31, 2011

doi:10.5539/eer.v1n1p12 URL: http://dx.doi.org/10.5539/eer.v1n1p12

\begin{abstract}
It is believed that the organizational inefficiency of the 'BPDB' and 'Power Division' of Ministry of Power, Energy, and Mineral Resources (MPEMR) of Bangladesh is the main cause for current electricity crisis. Although there are changes in public sector management in the electricity sector of Bangladesh due to the NPM, the organization continue to value the bureaucratic and hierarchical organizational culture. Bangladesh government has taken several programs and has adopted policies for privatization and public-private-partnership. Still the Bangladesh government has not succeeded to mitigate the crisis. This industry faces long time negligence, corruption and inefficiency. Currently the crisis situation has become acute due to inadequate fund, weak governance and above all inefficiency. But the political interferences in organizational management, in bureaucratic activities, in personnel management and even in private investment process, are creating a huge problem for the development of this sector. This paper defines the Organizational management, efficiency, and weak governance of Bangladesh's electricity industry. This paper examines the extent to which the electricity crisis of Bangladesh is the result of organizational inefficiency of the 'BPDB' and 'Power Division' of Ministry of Power, Energy, and Mineral Resources (MPEMR) of Bangladesh. This organizational inefficiency is actually shared between inefficiency of public organization and political interferences. It is discussed in this paper not only the organizational inefficiency causes the electricity crisis but also political interference, wrong policies , inadequate fund also responsible. This paper will show how the organizational culture, structure and strategies of the ministry and BPDB have resulted in the crisis. Moreover country's corrupted and chaotic political system, the roles of parliament and civil servants are also discussed in this essay. Current electricity crisis can be considerably overcome by increasing the efficiency of the 'Power Division' as well as by stopping the political interference in decision making and in bureaucracy.
\end{abstract}

Keywords: Electricity crisis, Organizational inefficiency, Bangladesh

\section{Acronym}

ADB - Asian Development Bank

BAC - Bureau of Anti-Corruption

BERC - Bangladesh Energy Regulatory Commission

BPDB - Bangladesh Power Development Board

CBA - Collective Bargaining Agent

CEI - Chief Electrical Engineer

DESA - Dhaka Electric Supply Authority

DESCO - Dhaka Electric Supply Company Limited

EGCB - Electricity Generation Company of Bangladesh

EPWAPDA - East Pakistan Water and Power Development Authority

IMF - International Monetary Fund

IPP - Independent Power Project

KWth - Kilowatt-hour (=1,000 watt-hours) 
MoU - Memorandum of Understanding

MP - Member of the Parliament

MPEMR - Ministry of Power, Energy, and Mineral Resources

MW - Megawatt (=1,000 KWh)

NPM- New Public Management

PDB - Power Development Board

PGCB - Power Grid Company of Bangladesh

PPA - Power Purchase Agreement

PPR - Public Procurement Regulation

PSRB - Power Sector Reforms in Bangladesh

REB - Rural Electrification Board

RFCD - Required Financial Closing Date

SBU - Strategic Business Unit

SPP - Small Power Plants

TIB - Transparency International Bangladesh

UNDP - United Nations Development Program

USAID - United States Agency for International Development

WAPDA - Water and Power Development Authority

WZPDCL - West Zone Power Distribution Company Ltd.

\section{Introduction}

In a public sector organization, efficiency measures the extent to which the organization is producing the maximum possible output for the benefit of the people from the available inputs (Madden et al., 1997). Although the Bangladesh government and people have been facing a huge electricity crisis since 1990, currently this crisis has become so acute that the law makers of the ruling party (Bangladesh Awami League) feared public anger (Zekeyo, 2001; Gutierrez, 1996; World Bank, 2001; "Lawmakers fear public anger....", 2010). According to BPDB (2010) and Power Cell (2010) Bangladesh Power Development Board generates 3,812 (MW) of the country's 5,803 MW of total commercial electricity (66\% of the total installed capacity) whereas private companies generate 1765 MW (30.43\% of total capacity) (Power division, 2010). Power outage/failure is a common phenomenon now-a-days and people are facing severe electrical load shedding, voltage fluctuation throughout the day and this problem is more severe in the rural areas, although only $30 \%$ of the total population enjoys the electricity facilities (TIB, 2007).

It is assumed that the organizational inefficiency in this sector is the main cause for this crisis (Gutierrez, 1996; Zekeyo, 2001; Rudnick, 1996; World Bank, 2001b). Bangladesh Government had to deploy Army for controlling the angry people and electricity, gas, water crisis managements ("Lawmakers fear public anger....", 2010). Although present ruling party Bangladesh Awami League made election pledges to solve the crisis soon (Bangladesh Awami League, 2010), it has not succeeded yet. At present 'Power Division', a part of the Ministry of Power, Energy, and Mineral Resources (MPEMR) of Bangladesh controls the electricity supply industry through the Power Cell (Sarkar et al, 2003). But, under the co-ordination and guidance of the Power Division, BPDB, a holding company, is solely responsible for generating, transmitting and distributing power through PDB, DESA, DESCO, WZPDCL and REB/PBSs though out the country. It is argued that the electricity crisis has taken place due to the organizational inefficiency such as misuse, system loss and corruption in electricity supply sector (Haque \& Rahman, 2010). This paper examines the extent to which the electricity crisis of Bangladesh is the result of organizational inefficiency of the 'BPDB and Power Division' of Ministry of Power, Energy, and Mineral Resources (MPEMR) of Bangladesh. This organizational inefficiency may be shared between government organization and political interferences. It is discussed in this paper not only the organizational inefficiency causes the electricity crisis but also political interference, wrong policies, inadequate fund also responsible. This paper will show how the organizational culture, structure and strategies of the ministry and BPDB have resulted in the crisis. These investigations will ultimately present a better understanding of the current electricity crisis in Bangladesh. 


\section{Concept of 'Organization', 'Public Organization' and 'Management'}

\subsection{What are 'Organization', 'Public Organization' and 'Management'?}

Tayeb (1994) argues that, an organization comes into being when a person or a group of people decides to achieve a common goal with the collaboration of one or more people although Gortner et al. (2007) argues that, a group of people makes an organization to accomplish a goal. Tayeb (1994) further states that, subsequent activities of an organization are all based on the decisions made by the people.

Gortner et al. (2007) categorizes organizations as, government, nonprofit and private and includes government and nonprofit organizations under the rubric of 'public organization'. Public organization is an organization whose primary goal or mission is providing goods or services that benefit members of public rather than stakeholders and owners of the organizations (Gortner et al., 2007). Goodsell (2004) includes 'bureaucracy', the unelected part of the government as the institutions of public organization and public administration. Ministry of Power, Energy, and Mineral Resources (MPEMR) of Bangladesh controls the electricity industry through power division and power cell that are government and non-profit public organizations (BPDB, 2010). Simon and Thompson (1991, p. 42) discusses that public organizations are more directly open to political influence than private organizations. All public organizations are not equally open; rather the degree of organizational self-containment is important (Simon and Thompson 1991, p. 42). However, Jorgensen et al. (1998) describes the relations between the ministries and the public organization as formal relations of authority that mould the organizations into the political systems and that is subject to ministerial control. Naturally, a public organization can adjust itself to the desires of the ministry and ensure 'orderly conditions' as to allocation of appropriations and administrative systems according to the political agenda (Jorgensen et al., 1998). In Bangladesh Power Division and Power Cell are working according to the desire of the Ministry of Power, Energy, and Mineral Resources (MPEMR) and political agenda of the government.

Management is inherently a generic process with universal implications and with application in any institutional setting, whether a private firm or a public organization (Murray, 1975 \& Anheier, 2000). On the other hand Moore (1984) suggests that, the gist of public management is 'conceiving and implementing public policies that realize the potential of a given political and institutional setting' (Moore, 1984, p. 3).

\subsection{NPM in organizations}

New Public Management (NPM) has become familiar across the world from its lands of origin in the Anglo-American nations (Turner, 2002). Common (1998) shows that first attempt of NPM appeared in the decade of 1980s as a result of budgetary restraint that took place within the framework of administrative strength afforded by the traditional Western bureaucracies. Moreover some scholar argue that, the words of NPM are articulated in different places of the world differently such as in Malaysia and Singapore 'quality management', in the UK 'privatization' and in most of counties 'decentralization'(Common, 1998; Wright, 1994; Bennett, 1991). Bangladesh has learnt 'privatization' policy from UK in the process of NPM (Common, 1998; Wright, 1994; Bennett, 1991). Common (1998) argues that, international institutions such as the World Bank, IMF, European Union, and OECD have 'globalized' the principles and practices of NPM by spreading it (Common, 1998).

The NPM has sought to achieve a greater orientation towards reform, change, flexibility, entrepreneurialism, outcomes, efficiency and productivity (Orchard, 1998). It has also incorporated support for more participatory and flexible form of organization designed to achieve organizational goals (Williams, 1992). Parker \& Bradley (2000) find that, despite the changing nature of the public sector management due to the NPM, these organizations continue to value the bureaucratic and hierarchical organizational culture. This situation is prevailing in the Bangladesh electric power supply industry also (BPDB, 2010).

\subsection{Concept of organizational efficiency in public organization}

Jreisat (1997) suggests that organizational efficiency usually includes acquiring, protecting and using it resources (personnel, property and space) economically and inefficiency causes due to the wasteful practices whether the organization is complying with laws and regulations. Pollitt (2000) describes the criteria of efficiency more broadly: savings, improved processes, improved efficiency, greater effectiveness, and an increase in the overall capacity of the administrative system as a whole.

\subsection{Organization characteristics, mismanagement and misconduct}

Explaining organizational characteristics, Jorgensen et al. (1998) considers that, public organizations are connected in a diplomacy and negotiation network that includes the organization and all external influencing actors. Super-ordinate authorities such as the parent ministry, the cabinet are among the actors and also include Members of Parliament, interest organizations, unions and organized consumers (Jorgensen et al., 1998). 
Jorgensen et al. (1998) argues the organizations basically try to negotiate through these networks and uphold long-term relationships of support only for survival. However, Staw et al. (1981) argues that high levels of centralization provide greater coordination but less flexibility and rapid decision-making in a crisis creates burdensome procedures.

Vaughan (1999) defines organizational misconduct as the acts of omission or commission by individuals or groups of individuals who violate their own organizations' internal laws, rules, or administrative regulations on behalf of organization goals. Alternatively she states the violation of formal design goals and normative standards and expectations as the organizational mistakes (Vaughan, 1999). Aubert (1952), Simmel (1950) ,Vaughan (1992) and Vaughan (1999) consider organizational mistake and misconduct such as 'White color crime', 'corruption', 'abuse of power', as the organizational deviance or mismanagement that ultimately harm public and public have to pay for these.

Vaughan (1992) argues that the relational ties within organizations that generate trust and control malfeasance provide members with opportunities for deceit and misconduct. Crozier (1964) argues that a bureaucratic system of organization cannot correct its errors because the feedback process does not function well. This situation often takes place in Bangladesh's electricity industry (TIB, 2007). Theft, misconduct and misappropriation are there (TIB, 2007). These events are considered as the inefficiency of the organizations.

\subsection{Private-public partnership: Multi-organizational partnership}

From a public management perspective public-private partnerships can be defined as "the formation of cooperative relationships between government, profit-making firms, and non-profit private organizations to fulfill a policy function" (Linder and Rosenau, 2000, p.5).Multi-organizational partnerships are organizational structures that are not identical with the network mode of governance (Lowndes, 1998). Multi-organizational partnerships have a specific similarity with network modes of governance, but that in a different ways of the partnership life cycle, hierarchical and market relationships (Lowndes, 1998). Bangladesh Government followed the single buyer model initially, although the Power Grid Company was acting as the market operator and the single buyer (GOB, 2004; Fichtner \& Power Cell, 2006). As the industry becomes mature, the country is moving to a multi-buyer multi-seller market structure and multi-organizational partnership (Bhattacharya, 2007).

\section{Background and Present Organizational Structure of the Electricity Industry}

The universal feature of the organization structure can be considered as visible structure, as described in terms of dimensions such as centralization of decision-making, ownership pattern, standardizations of procedures, extensive use of written rules and regulations, specialization of roles and functions (Pugh et al. ,1968). Current structure of Bangladesh's Electricity supply industry also has the universal feature of a typical organization.

\subsection{Initial ownerships}

Electric power generation was started in 1901 in the then Dhaka city of Bangladesh (the then Bengal under British rule) by a personal initiative (BPDB, 2010). The public sector entered into the industry when the government established improvement of power sector Electricity Directorate in 1948, Water and Power Development Authority (WAPDA) in 1959 for further development of the electricity supply industry (Alam et al., 2004). After the emergence of Bangladesh in 1971 the Government created Bangladesh Power Development Board (BPDB) in 1972 (BPDB, 2010). The Government started major reformation in this industry by establishment of Rural Electrification Board (REB) in 1977, Dhaka Electricity Supply Authority (DESA) in 1991, and Dhaka Electric Supply Company (DESCO) in 1998 (Malek, 2004).

\subsection{Present structure of the industry}

At present electricity supply industry of Bangladesh is controlled by the Ministry of Power, Energy, and Mineral Resources (MPEMR) (Sarkar et al., 2003). The ministry controls this industry through Power Division and Power Cell, which were established in 1998 to regulate, to manage, and to lead the electricity supply industry reform programs (World Bank, 2001; Sarkar et al, 2003).

State-owned 'Power Grid Company of Bangladesh (PGCB)' is responsible for transmission only and electricity generation and distribution activities are opened to private, public and foreign involvement, although Government owned bodies are still dominating (Sarkar et al., 2003). An autonomous body named 'Energy Regulatory Commission', that has the authority to issue licenses, ensure compliance with license conditions, and set tariffs, was established in 2003 (World Bank, 2003).

\section{Electricity Crisis: To What Extent Organizational Inefficiency}

Bangladesh electricity supply industry is controlled by the centralized bureaucratic system of the Ministry of Power, Energy, and Mineral Resources (MPEMR) and its subordinate organizations Power Division and BPDB. 
It is believed that the organizational inefficiency along with other factors is responsible for the current electricity crisis.

\subsection{Organizational structure and Reform Policy}

Kerr and Savelsberg (2001) argue that reformation is done by the state for welfare of the people. The locus of responsibility for welfare is refocused in what we see as part of a broader new social agenda which encompasses changed roles, expectations, rights and responsibilities for individuals, organizations, and governments (Kerr and Savelsberg, 2001). Alam et al. (2004) argues that, the Bangladesh government has kept the electricity business in its jurisdiction with a view to serve the mass people either in the name of corporate body or of company as this industry has an immense social, political and economic importance. As a result Bangladesh electricity supply industry is highly centralized within the bureaucratic system, although private participation is there (Alam et al.,2004). Tayeb (1994) discusses that, high degree of centralization means all the decisions are taken at the top of the organizational hierarchy. It this situation the employees cannot express their opinions and it does not reflect the consultations and information exchange (Tayeb, 1994). In Bangladesh all the decisions are taken by the cabinet and the ministry without consulting with the stakeholders ("PM approves emergency power plant......", 2010).

\subsection{Privatization and Public-Private-partnership}

Williamson (2002) discusses that, the main rationale for privatization is the belief that private industry is managed more efficiently than state enterprises, because of the more direct incentives faced by an organizational manager who either has a direct personal stake in the profits of an enterprise or else is accountable to those who do. But, in Bangladesh public-private-partnership or privatization take place in the case of urgency and emergency rather than increase efficiency of the electricity supply industry (Gratwick and Eberhard, 2008). Independent Power Producers (IPPs) take part in electricity generation under privatization and private-public partnership policy of Bangladesh government at the moment when government funds are not available and crisis in electricity supply becomes acute (World Bank, 2003; TIB, 2007). Although Bangladesh adopted electricity supply industry reformation policy and the private sector power generation policy in 1996 to encourage private investment in this industry (BOI, 2010; World Bank, 2003), it takes a long process for approval of these IPPs projects due to political influence, corruption and inefficiency ("Lengthy process sets back power projects...", 2010).

\subsection{Electricity crisis due to organizational weaknesses}

Electric supply industry of Bangladesh subsidizes its residential customers as well as its commercial and industrial customers, although the industry is not able to meet their operational costs (Khan, 2003). Khan (2003) suggests that, the Government of Bangladesh (GoB) funds to Rural Electrification Board (REB) to meet the revenue deficit and the operational losses. REB and DESA in Bangladesh also receive power from BPDB at subsidized rates. Temple (2002) estimates that, in the year 2002, the average cost of electricity supply was taka 3.08 per $\mathrm{kWh}$ whereas, the average selling price of BPDB was below its cost of supply, providing a total subsidy of 12170 million taka to its customers in the year 2002. The losses of BPDB have been attributed to mainly three factors: Low Average tariff, high system losses of (including pilferage, non-billing, non-payment of bills, etc) and low rate of bill recovery (ADB, 1997; Rahmatullah, 2001).

\subsection{Inefficient organizational management}

In view of the fact that BPDB has been in losses, unable to recover its operation cost through sales revenue, the subsidy to REB come from public funds rather than cross-subsidization from BPDB's other customers (Alam et al., 2004). Alam et al. (2004) argues that, these losses implied that allocation to BPDB by the government could not be fully utilized for capital investment in expanding electricity infrastructure. Also it is likely that this affected the available resources with the government for allocation to the rural electrification program (TIB, 2007).

\subsection{Corruption}

Klitgaard (1988) defines corruption as "the abuse of office for personal gain". In Bangladesh electricity supply industry corruption takes many forms, ranging from grand corruption - the capture of high office of government by elites and the uses of these offices for private gain - to "petty" corruption - the use of bribes or other "facilitating payments" to provide services, bend or break laws (TIB, 2007; Azfar, 2002; Johnston, 1996) . TIB (2007), World Bank(2003), Newbery(2006) \& Smith(2004) think Bangladesh electricity supply industry suffers from all sort of malpractices and inefficiencies, particularly 'corruption'. Ahmad (2007) argues that, corruption takes place because of inadequacies in existing public management systems as well as in social and cultural role 
of communal bonds and kinship ties within social framework'. On the other hand Mauro (1993), opines that, 'speed money'or 'bribe' helps to conquer the 'bureaucratic red tape' works as motivation for the industrious government employees. Due to the alleged corruption in the electricity supply industry the present Prime Minster and ex-Prime Minister along with their political and bureaucratic colleagues were arrested and they are still facing the court (Bangladesh Awami League, 2010).

4.6 Weak governance: Theft and lack of accountability

Accountability covers the issues such as, making the elected representatives to answer for their policies to the voters, making the public servants answerable for their mistakes and seeking redress from government agencies and officials by the member of public (Mulgan, 2000). Mulgan (2000) suggests that there should be a relation between accountability and efficiency and accountability leads to responsibility for political and managerial aspects. Laking (2001) and Khan (2003) argue that, the main form of corruption in Bangladesh Power Development Board (BPDB) and Dhaka Electric Supply Authority (DESA) is system loss and the employees of these organizations are responsible for that loss. System loss occurs mostly due to the theft of electricity by unauthorized connections and unpaid bills and the employees of these organizations assist these activities (Smith, 2004; Khan, 2003; Laking, 2001). Engineers of the electricity supply industry oppose the reformation process as their professional body named, 'Institution of Engineers in Bangladesh (IEB)' that is controlled by the political leaders, is partly against the reformation process in this sector (Bhattacharyya, 2003; IEB, 2000). Hill and Lynn (2004) demonstrate that, political actors who pursue their interests through the hierarchical structures of national political institutions control over the officers and organizations having the administrative authority and thus the staffs are not formally accountable to anyone.

\subsection{Other weaknesses}

Apart from the organizational inefficiencies there are some other factors those are considered as equal responsible for the current electricity crisis.

\subsubsection{Wrong policy}

Governance framework has the power to make policy and its implementation quite different from reformers' intentions (Boyne et al. 2003). Forbes et al. (2004) suggests that different levels of governance influence one another, that is, that the organization of governance impacts what, how, and for whom public services are provided. Public managers control formal structures and authority below the level of national policy making, other discretionary choices by public managers, and the characteristics of service provision (Forbes et al., 2004). TIB (2007) finds that due to the indecision of the Power Division of Bangladesh in policy formulation process some proposed power plants both in the public and private sectors could not start its operations on time and thus the crisis has been deepen in these days. On the other hand wrong site selection and wrong policies to build new power plants are also responsible for the delay (TIB, 2007).

\subsubsection{Insufficient Government funding}

USAID-SARI/Energy (2007) finds that Bangladesh Government had insufficient fund for electricity supply industry since its emergence as electricity generation, transmission and distribution require large financial investment. Bangladesh's electricity generation plants have been constantly incapable to meet system demand since 1990s (Newbery, 2005). Newbery (2005) argues that, shortages of government funds for electricity generation plant maintenance and for installation of new plants have created this acute problem in Bangladesh.

\subsubsection{Inadequate public-private investment}

Bangladesh started 'privatization' and 'public-private-partnership'in 1994, consulting with the World Bank and Asia Development Bank (ADB, 2001). MacEwan (2002) argues that, as the private company earns enormous profits for its owners, 'privatization' is not always suitable and it is particularly tricky when it swaps an inefficient government monopoly. (Newbery, 2006) thinks that, Bangladesh have been more successful than India in continuing to attract foreign private investment, although it was the most corrupt country in the world till 2005.On the other hand Bhuyan (2009) argues that, although Bangladesh adopted 'private sector generation policy' in 1996 and declared its vision in 2000, it has not received significant amount of investments in this sector ever after a decade. Experts, businesspersons, donors think there are still scope to invest in Bangladesh electricity supply industry (“Enough scope to invest in power sector......", 2010).

4.7.4 Long term absence of government oversight

Womukonya (2003), TIB (2007) and (Bhattacharyya, 2007) identify many causes of the crisis those are not properly over-sighted by the government over the years, although those are creating current electricity crisis: 1) 
Strong labor unions but lower public-sector wages; 2) Outdated and robust machineries and plant design; 3) Inferior quality of incoming electric power; 4) Poor maintenance and weak system of metering customers; 5)Illegal connections, tampered meters and uncollected bills ; 6)Weak legal measure for unpaid bills;7) insufficient fund for maintenance and investment;8)Demand exceeds capacity and distorted tariffs; 9) High subsidies.

Although Bangladesh has a strong and effective act, "Electricity Act, 1910" to prevent electricity theft and to collect unpaid bills, it is not enforced properly due to malpractice and negligence of court (TIB, 2007; Smith, 2004). TIB (2007) opines lower-wage, but strong labour union (CBA) causes corruption within an organization.

\section{Other Responsible Factors: Not Only the Organizational Inefficiency}

Roles of the politicians, civil bureaucrats as well as the private investors are also responsible for the electricity crisis. Boyne (2003) finds seven types of service performance indicators: quantity of output, quality of outputs, efficiency, equity, outcomes, value for money, and consumer satisfaction. However, Forbes et al. (2004) argues that, political-system interactions in principle might influence government performance that offers several potential advantages and disadvantages in the design and analysis of the determinants of public organization performance.

\subsection{Politicians' role}

Public organizations are more directly open to political influence than private organizations. But public organizations are not equally open; rather, it is important to be aware of the degree of organizational self-containment (Simon \& Thompson, 1991, p. 42). Political corruption becomes a systemic feature of information age politics. Since character assassination needs some substance from time to time, systemic political corruption provides ample opportunity, as a market of intermediaries is created to leak and counter-leak damaging information (McNeil, 1978). In political corruption is devoted primarily to the public sphere in which political actors operate (Heywood, 1997). Bangladesh always faces extremely confrontational, non-cooperation, partisan politics and almost all the parties have been blamed for corruption in power sector (Bhuyan, 2009; Bhattacharyya, 2007). Moreover, present bipolar political setting and the hatred politics between ruling alliance and opposition alliance lead to paralyzing the roles of the government (Bhattacharyya, 2007; Economist, 1999). In this crisis the same situation is prevailing and ruling alliance, including the Prime Minister is blaming previous government alliance (present opposition alliance) for the current electricity crisis(Bangladesh Awami League, 2010).

\subsection{Civil servants' activities}

Forbes et al. (2004) argues that staff satisfaction, performance-related pay, personnel stability, job security, and staff morale act as variables for better performance of the civil servants. Transparency International, Bangladesh survey carried out in 2000-2007 found that government losses revenue greatly due to the corruption of the civil servants in electricity supply industry and in the ministry (TIB, 2000; TIB, 2007; Khan, 2003). Recently the Prime Minister of Bangladesh blamed the bureaucrats for the backdrop of a dull rate of implementation of the development projects including the electric supply sector (Hossain, 2010). In a conference, experts of electricity sector, intellectuals, businesspersons, other elites also criticized the bureaucrats saying, in Bangladesh a power project, public or private, needs to hurdle over at least five major committees for getting approval, which sometimes takes years under the existing process'(“Lengthy process......", 2010).

\subsection{Role of private investors}

Privatization can be very constructive where it results in increased competition, and useful where it eases fiscal pressures, but public service is always inferior to private acquisitiveness as a motivating forces (Williamson, 2002). Williamson (2002) investigates that, under certain circumstances, such as where marginal costs are less than average costs ,it is too complex to be easily compensated by regulation (for example, in the case of electricity supply) and thus he believes public ownership is preferable than private enterprise. But in the case of Bangladesh private investors are also selected among the politicians of the ruling party (TIB, 2007). As a result inexperienced investors creates problem in building new power plants.

\subsection{Activities of parliament}

Bevir et al. (2003) argues that, the reform (NPM) processes ensure the parliamentary debates and questions, committee hearings in most of the developing nations as well as Bangladesh. The World Bank (2003) praises the role of Bangladesh Parliament named, 'Jatiya Sangsad' that it helps to pass the electricity reforms related acts. Khan (2003) asserts that, The Jatiya Sangsad (parliament) should be the focal point of all activities in a parliamentary democracy. He further says that the parliament has become the medium for passing bills for ruling 
government (Khan, 2003). Although Khan (2003) says, the Parliamentary Standing Committees do not work effectively, the electricity crisis issues were discussed several times and the PM along with her other colleagues placed the current status and strategies of the crisis mitigation in the parliament ('1,200 MW more power.....', 2010). Again, sometimes the ruling party does not want to discuss the electricity crisis issues, even though the opposition party demands ('JS SESSION ROUND-UP........', 2010). So, Parliament is also politically driven and not playing any vital role for this crisis.

\subsection{Roles of the multilateral organizations and donor agencies}

World Bank (2003) identifies that, due to high system loss, large account receivables, the poor management and inability to rationalize tariff rate and introduce other reforms, concessional loan for the power sector from the multilateral development partners was not available. Consequently, needed investments for generation, transmission and distribution of electricity could not be made. The losses to BPDB in Bangladesh also adversely affected availability of financial resources from multilateral institutions as they withdrew from financing the power sector in Bangladesh (Alam et al., 2004).

\section{Government's Strategies to Meet the Crisis: Impact on the Organization}

The cabinet of Bangladesh government and the ministry have taken some immediate strategies as well as long term strategies to overcome the electricity crisis.

\subsection{Immediate strategies}

The Bangladesh government and the Prime Minister have taken some instant measures to reduce social unrest and dissatisfaction: Prime Minster and her cabinet rapidly approved some huge projects that are also have allegation of corruption, without following the rules and laws ("PM approves emergency power plant......", 2010). Power Division, BPDB carried out decisions of shutting down some fertilizer factories and diverting gas for power generation, rationing the use of air conditioners in private homes/offices, $1 \mathrm{hr}$ electricity outage every alternate hour ("PM Orders $1 \mathrm{hr}$ Outage ........", 2010). All these were contingency approach of the Ministry, Power division and BPDB though no measures have been taken to enhance organizational efficiency and to stop political interference.

\subsection{Long-term strategies}

The Cabinet of Bangladesh government and the power division of the ministry have taken some immediate but long term strategies to mitigate current electricity crisis. Some of the mentionable strategies are: project to build ten "peaking power plants" and project to modify and renovate the old generation units which will produce electricity in 2011 ("Cabinet body approves 3 rentals ........", 2010). Bangladesh is going to install a nuclear power station with the help of Russia and going to import electricity from India, Nepal, Bhutan and Myanmar ("Dhaka and Moscow sign nuclear....", 2010).

\section{Conclusions}

Inefficient organizational management of the Power Division of the Ministry of Power, Energy, and Mineral Resources (MPEMR) as well as the BPDB has partially created current electricity crisis in Bangladesh. The influences of the three other major factors, i.e., financial resources, adequate generation capacity, private investment are also important for electricity generation along with the organizations efficiency and effective policy. Even the private sector participation and reformation processes have not been succeeded to overcome this crisis. Political interference and corruption in private investment and in bureaucracy as well as the conflicts between ruling party and opposition have more aggravated this crisis. Ineffective Parliamentary supervision, centralized organizational structure, bureaucratic culture and weak strategies to increase electricity productions are also criticized. Current crisis in electricity sector can be considerably overcome by increasing the efficiency of the 'Power Division' and 'BPDB' as well as by stopping the political interference in decision making and in bureaucracy.

\section{References}

A costly feud in Bangladesh (1999, November 18). The Economist. p. 45. Retrieved September 24, 2011 from http://www.economist.com/node/260161

ADB. (2001). Power sector reform. Quarterly economic update, March 2001, Bangladesh: Asian Development Bank, Bangladesh Resident Mission.

Alam, M. S., Kabir, E., \& Chowdhury, M. A. K. (2004). Power sector reform in Bangladesh: Electricity distribution system. Energy, 29, 1773-1783. http://dx.doi.org/10.1016/j.energy.2004.03.005 
Andersen, A. (2001). Global Best Practices in Power Sector Reform: Confederation of Indian Industry. India: Arthur Andersen Pty Ltd.

Anheier, H. K. (2000). Managing nonprofit organizations: Toward a new approach. Civil Society Working Paper, January 1.

Aubert, V. (1952). White-collar crime and social structure. American Journal of Sociology, 58, 263-271. http://dx.doi.org/10.1086/221148

Azfar, O. (2002). Corruption. In Encyclopedia of Public Choice (Eds.), IRIS: University of Maryland, College Park. http://dx.doi.org/10.1023/A:1019943100310

Bacon, R. W. (1995). Privatization and Reform in the Global Electricity Supply Industry. Annual Review: Energy and the Environment, 20, 119-143. http://dx.doi.org/10.1146/annurev.energy.20.1.119

Bacon, R. W., \& Besant-Jones, J. (2002). Global Electric Power Reform, Privatization and Liberalization of the Electric Power Industry in Developing Countries, The Energy and Mining Sector Board, The World Bank Group, Energy \& Mining Sector Board Discussion Paper Series 2.

Bangladesh PM Orders 1 hr Outage Every Alternate Hour. (Apri 8, 2010). Energy Bangla. Retrieved November 5, 2010 from http://www.energybangla.com/index.php?mod=article\&cat=PowerSector\&article $=2432$

Bangladesh Power Development Board (BPDB), (2010). Retrieved June 3, 2010 from http://www.bpdb.gov.bd/

Bennett, C. (1991).What is policy convergence and what causes it? British Journal of Political Science, 21, 215-33. http://dx.doi.org/10.1017/S0007123400006116

Bevir, M., Rhodes, R. A. W. and Weller, P. (2003). Traditions of governance: interpreting the changing role of the public sector. Public Administration, 81(1), 1-17. http://dx.doi.org/10.1111/1467-9299.00334

Bhattacharyya, S. C. (2007). Power sector reform in South Asia: Why slow and limited so far? Energy Policy, 35, 317-332. http://dx.doi.org/10.1016/j.enpol.2005.11.028

Bhuyan, A. R. (2009). Challenges for the Bangladesh Economy: Priority Economic Agenda for the New Government. Thoughts on Economics, 19(1), 1-19.

Bogason, P. \&. Musso, J. A. (2006). The Democratic Prospects of Network Governance. The American Review of Public Administration, 36(3). http://dx.doi.org/10.1177/0275074005282581

Boyne, G. A., Farrell, C., Law, J., Powell, M., \& Walker, R. M. (2003). Evaluating public management reforms: Principles and practice. Buckingham, UK: Open University Press.

Boyne, G. A. (2003). Sources of public service improvement: A critical review and research agenda. Journal of Public Administration Research and Theory, 13 (3), 367-394. http://dx.doi.org/10.1093/jpart/mug027

Cabinet body approves 3 rental power projects without tender. (May 27, 2010). The Bangladesh Today. Retrieved November 5, 2010 from http://www.thebangladeshtoday.com/archive/May\%2010/27-5-2010.htm

Common, K. R. (1998). Convergence and transfer: a review of the globalization of new public management. International Journal of Public Sector Management, 11(6), 450-550. http://dx.doi.org/10.1108/09513559810244356

Crozier, M. (1964). The Bureaucratic Phenomenon. Chicago: Univ. Chicago Press.

Dhaka and Moscow sign nuclear cooperation deal: Russia extends full support for setting up nuclear power plants in Bangladesh. (May 22, 2010). The Bangladesh Today. Retrieved November 5, 2010 from http://www.thebangladeshtoday.com/archive/May\%2010/22-5-2010.htm

Dhaka Electric Supply Authority (DESA). (2010). Retrieved November 3, 2010 from http://www.desa.com.bd/

Dhaka Electric Supply Company (DESCO). (2010). Retrieved November 3, 2010 from http://www.desco.org.bd/

Eikenberry, A. M., \& Kluver, J. D. (2004). The marketization of the nonprofit sector: civil society at risk? Public Administration Review, 64(2), 132-141. http://dx.doi.org/10.1111/j.1540-6210.2004.00355.x

Encourage private investments in power sector. (May 6, 2010). The Daily Star. Retrieved November 6, 2010 from http://www.thedailystar.net/story.php?nid=137286

Enough scope to invest in power sector: Bangladesh business confidence improving. (February 14, 2010). The New Nation. Retrieved November 6, 2010 from http://www.ittefaq.com/issues/2010/02/14/news0853.htm

Fitchner \& Power Cell. (2006). Power sector Financial Restructuring and Recovery Plan. Power Sector Development Technical Assistant Project. Bangladesh Ministry of Power, Energy and Mineral Resources. 
Forbes, M., \& Lynn, Jr. L. E. (2005). How Does Public Management Affect Government Performance? Findings from International Research. Journal of Public Administration Research and Theory, 15, 559-584. http://dx.doi.org/10.1093/jopart/mui035

Godshell, C. T. (2004). The case for bureaucracy: A public administration polemic. ( $4^{\text {th }}$ ed.). Washington, DC: Congressional Quarterly Press.

Gortner, H. F., Nichols, K. L., \& Ball, C. (2007). Organization Theory: A Public and Nonprofit Perspective. Thomson Learning, USA :Wadsworth.

Gratwick, K. N., \& Eberhard, A. (2008). Demise of the standard model for power sector reform and the emergence of hybrid power markets, Energy Policy, 36, 3948-3960. http://dx.doi.org/10.1016/j.enpol.2008.07.021

Gutierrez, L. E. (1996). How do sub-Saharan African countries compare? In Symposium on Power Sector Reform and Efficiency Improvement in sub-Saharan Africa, Johannesburg, RSA: ESMAP Report No. 182/96 RSA, Dec 8-9, 1995.

Haque M. A., \& Rahman, J. (2010). Power Crisis and Solution in Bangladesh .Bangladesh J. Sci. Ind. Res., 45(2), 155-162. http://dx.doi.org/10.3329/bjsir.v45i2.5714

Heywood, P. (1997). Political Corruption: Problems and Perspectives. Political Studies, 45, 417-435. http://dx.doi.org/10.1111/1467-9248.00089

Hill, C. J., \& Lynn Jr., L. E. (2004). Is hierarchical governance in decline? : Evidence from empirical research. Journal of Public Administration Research and Theory, 15, 173-195. http://dx.doi.org/10.1093/jopart/mui011

Hossain, S. (2010, April 01). PM resents lengthy project execution process. The New Age. p.1. Retrieved November 4, 2010 from http://www.newagebd.com/2010/jun/01/front.html\#3

IEB, (2000). Comments on policy statement on power sector reforms. Retrieved from http://shakti.hypermart.net/electricity/

Johnston, M. (1996). Public Officials, Private Interests and Sustainable Democracy: When Politics and Corruption Meet. In Conference of Corruption in the World Economy (Chapter 3, p. 71). Washington, D.C: Institute of International Economics.

Jorgensen, T. B., Hansen, H. F., Antonsen, M., \& Melander, P. (1998). Public organizations, multiple constituencies and governance. Public Administration, 76(3), 499-518. http://dx.doi.org/10.1111/1467-9299.00114

Jreisat, J. E. (1997). Public Organization Management: The development of theory and process. Westport, CT, USA: Quorum Books.

JS SESSION ROUND-UP: Most burning issues omitted in discussion. (April 07, 2010). The New Age. Retrieved November 4, 2010 from http://www.newagebd.com/2010/apr/07/front.html

Khan, M. A. (2010, April 10). Crippling Energy crisis .The Daily Star. p.8.

Khan, M. M. (2003). State of Governance in Bangladesh, The Round Table, 92(370), 391-405.

Klitgaard, R. (1988). Controlling Corruption. Berkeley: University of California Press.

Laking, R. (2001). Bangladesh: the state of governance: Report prepared for the Asian Development Bank (ADB). Dhaka: ADB.

Larbi, G. A. (1999). The New Public Management Approach and Crisis States: UNRISD Discussion Paper No. 112. Geneva, Switzerland: United Nations Research Institute for Social Development.

Lawmakers fear public anger outburst over water, power: Army deployment from today to help WASA in water supply. (April 01, 2010). The New Age. Retrieved November 4, 2010 from http://www.newagebd.com/2010/apr/ 01/front.html\#1

Lengthy process sets back power projects. (April 14, 2010). The Daily Star. Retrieved June 6, 2010 from http://www.thedailystar.net/newDesign/news-details.php?nid=134312

Linder, S. H., \& Rosenau, P. V. (2000). Mapping the Terrain of the Public-Private Policy Partnership. In P.V. Rosenau, Public-Private Policy Partnerships (edition, pp.1-18). Cambridge MA: MIT Press.

Lowndes, V. \& Skelcher, C. (1998). The dynamics of multi-organizational partnerships: an analysis of changing modes of governance. Public Administration, 76(2), 313-333. http://dx.doi.org/10.1111/1467-9299.00103 
Madden, G., Savage, S., \& Kemp, S. (1997). Measuring Public Sector Efficiency: A Study of Economics Departments at Australian Universities. Education Economics, 5(2), 153-68. http://dx.doi.org/10.1080/09645299 700000013

Malek, B. G. M. A. (2004). Lecture on electricity as the driving force of the civilization: Bangladesh. 45th Convention, Institution of Engineers of Bangladesh, Khulna. Energy, 29, 1773-1783.

McNeil, K. (1978). Understanding Organizational Power: Building on the Weberian Legacy. Administrative Science Quarterly, 23(1), 65-90. http://dx.doi.org/10.2307/2392434

Ministry of Power, Energy and Mineral Resources. (2010). Private Sector Power Generation Policy of Bangladesh, 1996. Retrieved June 3, 2010 from http://www.powerdivision.gov.bd

Moore, M. H. (1984). A Conception of Public Management. In Teaching Public Management (edition, pp.1-12). MA: Harvard University Press.

Muhith sees far-reaching impacts of energy crisis. (April 14, 2010). The Daily Star. Retrieved November 6, 2010 from http://www.thedailystar.net/newDesign/news-details.php?nid=132890

Mulgan, R. (2000). 'Accountability': An ever-expanding concept. Public Administration, 78(3), 555-573. http://dx.doi.org/10.1111/1467-9299.00218

Murray, M. A. (1975). Comparing public and private management: An exploratory essay. Public Administration Review, July-August, 364-371. http://dx.doi.org/10.2307/974538

Newbery, D. (2006). Power Sector Reform, Private Investment and Regional Cooperation. In South Asia: Growth and Regional Integration (edition, pp.43-170). World Bank.

Orchard, L. (1998). Managerial, economic rationalism and public sector reform in Australia: connections, divergences, alternatives. Australian Journal of Public Administration, 57(1), 19-32. http://dx.doi.org/10.1111/1467-8500.00003

Parker, R. \& Bradley, L. (2000). Public sector: evidence from six organizations. International Journal of Public Sector Management, 13(2), 125-141.

People won't tolerate power crisis after 5-6 months: Subid Ali. (May 23, 2010). The Bangladesh Today. Retrieved November 5, 2010 from http://www.thebangladeshtoday.com/archive/May\%2010/23-5-2010.htm

PM approves emergency power plant without tender. (April 09, 2010). The New Age. Retrieved Nonember 4, 2010 from http://www.newagebd.com/2010/apr/09/front.html\#3

Pollitt, C. (2000). Is the emperor in his underwear: An analysis of the impacts of public management reform. Public Management Review, 2(2), 181-199. http://dx.doi.org/10.1080/14719030000000009

Power Cell. (2010). accessed on 03/11/2010 http://www.powercell.gov.bd/

Power Division. (2010). accessed on 03/11/2010 http://www.powerdivision.gov.bd/

Pugh, D. S., Hickson, D. J., Hinings, C. R. \& Turner, C. (1968). Dimensions of Organiztion structure. Administrative Science Quarterly, 13, 65-105. http://dx.doi.org/10.2307/2391262

Rahman, S. (2010, April 04).Energy crisis puts economy at risk: Businessmen warn of cut export earnings. The Daily Star. p.8. Retrieved November 4, 2010 from http://www.thedailystar.net/newDesign/latest_news.php?nid= 23235

Rahmatullah, B. D. (2001) Power sector reforms - a strategic proposition. Engineering News, Institution of Engineers, (January-February), 49. Dhaka.

Rahmatullah, B. D. (2001). System Loss in Power Sector: A major challenge for economic sustainability. Dhaka: Engineering News, Institution of Engineers; (May-June), 40.

REB. (2010). acessed on 03/011/2010 http://www.reb.gov.bd/

Simmel, G. (1950). The Sociology of Georg Simmel. Transl. ed. K Wolff. New York: Free Press

Simon, D. (1994). Crimes of the Criminal Justice System. Cincinnati, OH: Anderson.

Simon, H. A., \& Thompson, V. A. (1991). Public administration revisited. Society, 28(5), 41-45. http://dx.doi.org/10.1007/BF02695687

Smith, T. B. (2004). Electricity theft: a comparative analysis, Energy Policy, 32, 2067-2076. http://dx.doi.org/10.1016/S0301-4215(03)00182-4 
Staw, B. M., Sandelands, L. E., \& Dutton, J. E. (1981). Threat-rigidity effects in organizational behavior. Administrative Science Quarterly, 26, 501-524. http://dx.doi.org/10.2307/2392337

Tayeb, M. (1994). Organizations and National Culture: Methodology Considered. Organization Studies, 15(3), 429-446. http://dx.doi.org/10.1177/017084069401500306

TIB. (2000) .Corruption in public service departments. Retrieved from http://www.ti-bangladesh.org/docs/misc/ overview1.htm.

Transparency International Bangladesh (TIB). (2007). The State of the Governance in the Power Sector of Bangladesh: Problems and the Way Out. Dhaka: TIB.

Turner, M. (2002). Choosing Items from the Menu: New Public Management in Southeast Asia. International Journal of Public Administration, 25(12), 1493-1512. http://dx.doi.org/10.1081/PAD-120014258

Ullah, A. (June 05, 2010). Fixing problems of Bangladesh power sector. The Financial Express. Retrieved November 7, 2010 from http://www.thefinancialexpress-bd.com/more.php?news_id=97794

USAID: Bangladesh. (2010). Large Unsatisfied Demand for Energy', Energy, USAID: Bangladesh, Dhaka, viewed 8 November, 2010, http://www.usaid.gov/bd/programs/energy.html

USAID-SARI/Energy. (2007). 'Bangladesh: Energy sector overview', South Asian regional Initiative for Energy (SARI/Energy), USAID, Washington, viewed 8 November 2010, http://www.sari-energy.org/PageFiles/Countrie s/Bangladesh_Energy_detail.asp

Vaughan, D. (1992). Theory elaboration. In C Ragin , H. B., What is a Case?(ed., pp.173-202). New York: Cambridge Univ. Press.

Vaughan, D. (1999). The dark side of organizations: mistake, misconduct, and disaster. Annual Review of Sociology, 25, 271-305. http://dx.doi.org/10.1146/annurev.soc.25.1.271

Williams, T. A. (1992). Reforming Public sector work. Australian Journal of Public Administration, 51(3), 275-285. http://dx.doi.org/10.1111/j.1467-8500.1992.tb02613.x

Williamson, J. (2002). What Washington Means by Policy Reform. In J. Williamson, Latin American Adjustment: How much Has Happened? (Ed).Washington: Institute for International Economics.

World Bank. (1996). Bangladesh: Government That Works - Reforming the Public Sector. Washington, D.C.

World Bank. (2001). Global Development Finance 2001, World Bank, Washington D.C.

World Bank. (2003). Private Solutions for Infrastructure in Bangladesh, the International Bank for Reconstruction and Development, the World Bank, Washington, D.C.

World Energy Council. (1998). The Benefits and Deficiencies of Energy Sector Liberalisation: Volume 1(pp.121.) London: World Energy Council.

Zekeyo, J. P. (2001). Rural electrification reform and programme in Cameroon. In: Wamukonya, N. (Ed.), Proceedings of the African High Level Regional Meeting on Energy and Sustainable Development for CSD9. 